\title{
Erratum: Recent extensions of U.S. unemployment benefits: search responses in alternative labor market states
}

Robert G Valletta

Correspondence:

rob.valletta@sf.frb.org

\section{Erratum}

After publication of (Valletta 2014), it emerged that a number of errors had been introduced into the article due to a publisher error. Most importantly, in Table 5, the coefficient entry in the first row of Panel B, column (2), should have a negative sign in front of it (“-0.00514*"). Other errors largely pertain to display labeling and alignment and have been left as is for simplicity. Springer would like to apologize for any inconvenience caused.

Received: 5 February 2015 Accepted: 5 February 2015

Published online: 29 April 2015

\section{Reference}

Valletta (2014) Recent extensions of U.S. unemployment benefits: search responses in alternative labor market states. IZA J Labor Pol 3:18
- Convenient online submission

- Rigorous peer review

- Immediate publication on acceptance

- Open access: articles freely available online

- High visibility within the field

- Retaining the copyright to your article

Submit your next manuscript at springeropen.com 